\title{
Agronomic Engineering students' perceptions about agroecology: a case study at a public university in Tocantins
}

\author{
Deyla Paula de Oliveira1, Michele Ribeiro Ramos ${ }^{2}$ and Arison José Pereira ${ }^{3}$
}

\begin{abstract}
1 Pós-Doutora em Biologia Molecular pela Universidade Federal do Tocantins (UFT). Doutora e Mestre em Genética, Conservação e Biologia Evolutiva pelo Instituto Nacional de Pesquisas da Amazônia. Especialista em Microbiologia, Fundamentos e Biotecnologia pela UFT. Graduada em Ciências Biológicas pela Universidade Federal do Tocantins. Atualmente é Diretora de Amparo à Pesquisa e Financiamento Estudantil da Superintendência de Desenvolvimento Científico e Tecnológico do Estado do Tocantins e Diretora Científica e de Inovação da Fundação de Amparo à Pesquisa do Estado do Tocantins-FAPT, Brasil.

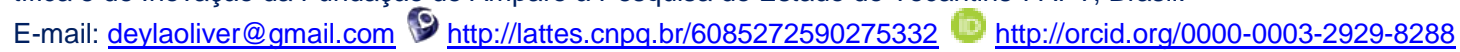

2 Doutora em Ciências Florestais pela Universidade Federal do Paraná, Mestre em Ciências do Solo pela Universidade Federal do Paraná, MBA Internacional em Gestão Ambiental pela Universidade Federal do Paraná, MBA em Gestão de projetos pela Universidade de São Paulo e Graduada em Agronomia pela Universidade Federal de Goiás. Atualmente é Professora na Universidade Estadual do Tocantins no curso de Engenharia Agronômica. Professora Adjunto I no Centro Universitário Luterano de Palmas CEULP/ ULBRA, Brasil.

E-mail: micheleribeiroramos2@gmail.com 9http://lattes.cnpq.br/1032124853688980 1 http://orcid.org/0000-0002-4818-4713

3 Doutor em Fitotecnia pela Universidade Federal Rural do Rio de Janeiro, Mestre em Fitotecnia e Graduado em Agronomia. Atualmente é Professor Universitário Doutor IV na Fundação Universidade do Tocantins (UNITINS), Brasil.

E-mail: arison.jp@unitins.br 19 http://lattes.cnpq.br/8809755672585322 1 http://orcid.org/0000-0001-9391-3738

ABSTRACT: The present study approaches the perceptions about agroecology of 30 university students from the $2^{\text {nd }}$ and $8^{\text {th }}$ periods of the Agronomic Engineering course at the State University of Tocantins. In order to collect the data, the students answered a questionnaire consisting of nineteen questions with multiple choices, but some questions were asked for justifications. The answers given to the closed questions of this qualitative-qualitative research were categorized in percentages and the open questions by the technique of content analysis. A significant portion of the students said their family members own rural property. Still, the students of the two periods mentioned that they have already heard about agroecology and conceptualized as an agriculture that uses less aggressive means to the environment. A significant portion is unaware of agroecological rural producers in Tocantins. However, for most of the $8^{\text {th }}$ period students, future farming will be based on the agroecology principles, while the $2^{\text {nd }}$ period students believe it will be fully technized. In addition, most of the students expressed interest in participating in research and/or extension projects in this area; since they know about sustainable food production practices and have already consumed some agroecological product. However, a great amount of students is unaware of the environmental service concept and believes that soy monoculture is a financially good initiative and environmentally poor.

Keywords: Agronomy. Teaching. University.

\section{Percepções dos estudantes de Engenharia Agronômica sobre agroecologia:} um estudo de caso em uma universidade pública do Tocantins

RESUMO: O presente estudo aborda as percepções sobre agroecologia de 30 estudantes universitários do $2^{\circ}$ e $8^{\circ}$ período do curso de Engenharia Agronômica da Universidade Estadual do Tocantins. Para a coleta dos dados, os estudantes responderam a um questionário constituído por dezenove questões com múltiplas escolhas, porém algumas questões solicitavam justificativas das respostas. As respostas dadas às questões fechadas dessa pesquisa de natureza qualiqualitativa foram categorizadas em porcentagens e as questões abertas pela técnica de análise de conteúdo. Uma parcela significativa dos estudantes disseram que seus familiares possuem propriedade rural. Ainda, os estudantes dos dois períodos mencionaram que já ouviram falar 
sobre agroecologia e conceituaram como a agricultura que usa meios menos agressivos ao ambiente. Boa parte desconhece produtores rurais agroecológicos no Tocantins. Contudo, para a maioria dos estudantes do $8^{\circ}$ período a agricultura no futuro será baseada nos princípios da agroecologia, ao passo que os estudantes do $2^{\circ}$ período acreditam que será totalmente tecnificada. Além disso, a maior parte dos estudantes manifestou interesse em participar de projetos de pesquisa e/ou extensão sobre a temática; disseram conhecer práticas sustentáveis de produção de alimentos e já consumiram algum produto agroecológico. Porém, a maioria dos estudantes desconhece o conceito de serviço ambiental e acredita que o monocultivo de soja é uma iniciativa boa financeiramente e ruim ambientalmente.

Palavras-chave: Agronomia. Ensino. Universidade.

\section{INTRODUCTION}

The conventional model of food production through the intensive use of agrochemicals is at odds with the sustainable concept due to the damages caused to fauna, flora, microbiota, soil and the dynamics of ecosystems. Given this, agriculture emerged from an ecological and sustainable perspective, also called agroecology (LIMA; CARMO, 2006).

This system proposes sustainable management alternatives with the aim of reducing the use of chemical inputs and based on low carbon agriculture, nutrient recycling and green manuring, providing nutrients for crops and maintaining soil structure and productivity. From this perspective, agroecology provides the transition from the conventional agriculture to styles of organic agriculture, with the consequence of the man establishment in the field, maintenance of ecosystems biodiversity and increase of food quality (OLIVEIRA; LIMA, 2017).

There is a growing consumption of foods with lower levels of contaminants around the world, which has contributed to boosting the consumption of organic foods and understanding the importance of agroecology for humankind. However, especially in places where the economy is focused on agriculture, such as the state of Tocantins, it is imperative that the theme agroecology is approached and taught in elementary schools, high schools and mostly in agricultural schools and higher education in agriculture.

Particularly for Agronomic Engineering professionals, it is expected that they will present multi and interdisciplinary skills, thus guaranteeing varied and complex skills, which will allow them to be active agents in actions to promote development in their area of study and formation (DIAS, 2008).

According to Soncini, Pierini and Gallo (2016),

as the agronomic engineer has direct contact with the rural producer, knowledge in agroecology is essential and allows that professional to better assist actions in the field in relation to the use of the space by this producer, the crop type which will be better used in relation to the climatic conditions of the place and the correct forms of production, without affecting biodiversity and without degrading the environment (SONCINI; PIERINI; GALLO, 2016, p. 308).

Considering that the agronomist has direct contact with the rural producer and in this respect, according to the Pedagogical Political Project of the Agronomic Engineering course at the State University of Tocantins-Unitins, the egress of the course must 
present the following characteristics:

solid scientific and professional training that allows to absorb and develop technology; critical and creative capacity to identify and solve problems, considering its political, economic, social, environmental and cultural aspects, with an ethical and humanistic vision in response to the demands of society; understanding and translation of the needs of individuals, social groups and communities, in relation to technological, socioeconomic, managerial and organizational problems, as well as the rational use of available resources, in addition to preserving the balance of the environment; ability to adapt, in a flexible, critical and creative way, to new situations; disseminate applied research and technological innovations in the agricultural sector; ability to analyze problems and synthesize solutions, integrating multidisciplinary knowledge; communication skills and leadership to work in diversified teams in their professional training and awareness of the need for continuous professional updating (PPP/UNITINS, 2010, p. 18-19).

Considering that the agronomist should present a solid, creative and critical profile for diverse subjects, such as agroecology, the knowledge of Agronomic Engineering students about this subject is highly important. Thus, this study approaches the perceptions about agroecology of university students of the $2^{\text {nd }}$ and $8^{\text {th }}$ periods of the Agronomic Engineering course at Unitins.

\section{MATERIAL AND METHODS:}

The locus of study is Unitins, Campus Professor Ruy Rodrigues da Silva, located in the municipality of Palmas, Brazilian State of Tocantins. The target audience consists of 30 students of the Agronomic Engineering course as a population and, as a sample,
$87.5 \%$ ( $n=21$ students) and 100\% ( $n=9)$ respectively of the $2^{\text {nd }}$ and $8^{\text {th }}$ course. The two groups were chosen to obtain the perceptions about agroecology of first-year students ( $2^{\text {nd }}$ period) and after coming in contact with agroecology through the discipline offered in the $7^{\text {th }}$ period of the course, in this case, students of the $8^{\text {th }}$ period.

This research has a qualitative-qualitative nature, since it was intended to identify and analyze the perceptions, attitudes and meanings obtained with the studied subject (MINAYO, 2012). For the data collection, the 30 students answered a questionnaire adapted from Sá-Oliveira, Vasconcelos and Silva (2015), consisting of nineteen questions with multiple choices, but some of them were asked for justifications. A questionnaire application is, according to Barros and Lehfeld (1990), a methodology that allows collecting information in a direct and systematic way, with the purpose of identifying the motivations and perceptions of a particular group of respondents regarding a particular object of study.

The questionnaire was applied to each individual form in the classroom, being filled out on a voluntary basis, by signing the Term of Free and Informed Consent TCLE presented and delivered to the respondents in the investigation. All the information collected was safeguarded and the participants confidentiality assured through the guidelines established in the norms 466/2012 of the National Council of Health CNS/CEP and with the objective of complying with the ethical principles of research with human beings.

The closed questions were analyzed based on the techniques of descriptive statistics of percentages and the justifications based on content analysis, according to 
Bardin (2009). The analyses of the transcriptions were carried out by highlighting the significant and important aspects of the students' speeches that allowed to identify and to understand the perceptions with respect to the agroecology.

\section{RESULTS AND DISCUSSION}

Based on the sample subjects and for a better understanding, a profile of the students interviewed in the $2^{\text {nd }}$ and $8^{\text {th }}$ periods of the Unitins Agronomic Engineering course was drawn. Thus, of a total of nine students interviewed from the $8^{\text {th }}$ period, $88.9 \%(n=8)$ were female and $11.1 \%(n=1)$ male, ranging from 20 to 30 years old (mean $=23$ years). Of these, $55.6 \%(n=5)$ lived in the rural area, and only $33.3 \%(n=$ 3 ) were born in the State of Tocantins, and none of the interviewees studied in an agricultural school, but two of them reported having studied Sciences Accounting and Technology in Agribusiness. However, the second period class had $52.4 \%(n=11)$ of male students and $47.6 \%(n=10)$ of female students, ranging from 17 to 23 years (mean $=18.7$ years). Of these, $33.3 \%(n=7)$ lived in rural areas, and $66.7 \%(n=14)$ were born in the State of Tocantins and $23.8 \%$ ( $\mathrm{n}$ $=5$ ) reported having studied in agricultural schools.

It is observed that in the $8^{\text {th }}$ period there was a predominance of women, whereas in the second period there was no significant difference between men and women. These data differ from those found in the study by Simonetti et al. (2015) on the profile of the participants of the Agronomic Engineering course at Assis Gurgacz College, in the municipality of Cascavel, State of Paraná, where the authors reported the predomi- nance of male students $(79.0 \%)$, with the age group of 17 to 20 years (72.0\%).

The analysis of the answers about the connection between the students and the rural environment showed that $44.5 \%$ ( $n=$ 4) of the families of the $8^{\text {th }}$ period students have rural property and that they attend this property during the vacation period. According to the students in the $2^{\text {nd }}$ period, $28.6 \%(n=6)$, respectively, have rural property, where these students usually attend on weekends and/or vacations (Table 1).

Table 1. Percentage of the of the interviewed students' answers, on the following question: What is its connection with the rural environment?

\begin{tabular}{|c|c|c|c|c|c|c|}
\hline Answers & $\begin{array}{l}\text { To- } \\
\text { tal }\end{array}$ & $\%$ & $\begin{array}{l}\text { Peri- } \\
\text { od }\end{array}$ & $\begin{array}{l}\text { To- } \\
\text { tal }\end{array}$ & $\%$ & $\begin{array}{l}\text { Peri- } \\
\text { od }\end{array}$ \\
\hline $\begin{array}{l}\text { My family owns and I go } \\
\text { there on weekends. }\end{array}$ & 6 & 28.6 & 20 & 3 & 33.3 & 80 \\
\hline $\begin{array}{l}\text { My family owns and I go } \\
\text { on vacation }\end{array}$ & 6 & 28.6 & 20 & 4 & 44.5 & 8음 \\
\hline $\begin{array}{l}\text { My family does not own } \\
\text { property, but I go on } \\
\text { vacation }\end{array}$ & 3 & 14.3 & 20 & 1 & 11.1 & 80 \\
\hline $\begin{array}{l}\text { My family does not own } \\
\text { property and I }\end{array}$ & 4 & 19.0 & 20 & 1 & 11.1 & 80 \\
\hline $\begin{array}{l}\text { My family does not own } \\
\text { property and I do not go } \\
\text { to rural properties }\end{array}$ & 2 & 9.5 & 20 & - & - & - \\
\hline TOTAL & 21 & 100.0 & - & 9 & 100.0 & - \\
\hline
\end{tabular}

Source: Prepared by the authors.

These data corroborate the study by Ramos et al. (2016) on the perceptions of students of the Technical High School in Agronomy and higher degrees in Agronomic Engineering and Agricultural Sciences of the Federal Institute of Mato Grosso (IFMT), Campus Confresa, where the authors detected that a representative portion of these students possessed properties and settlements in the region, or were children of rural landowners.

Other similar data were found by SáOliveira, Vasconcelos and Silva (2015) in a paper on environmental perception and 
assessment of the of awareness and knowledge degree about the risks and impacts caused by agrochemicals and the agroecological philosophy and practices of the $3^{\text {rd }}$ grade of high school students from four public schools in Macapá, State of Amapá, where the authors found that $62.6 \%$ ( $n=134$ ) of the interviewees had some link with the rural environment. According to the authors, the sporadic coexistence with the rural environment can contribute for students of in the agricultural area courses to present better perception and give greater importance to the environmental preservation and the use of agroecological methods.

Moreover, in the study by Simonetti et al. (2015), more than $50 \%$ of the students who graduated from the Agronomic Engineering course had their origins in agricultural activity. According to the authors, the fact that parents are rural producers could be an indication of the child's choice for a course of agronomy, however, with the objective of searching greater knowledge and making use of the technologies to increase productivity and profit in the parents' property.

Concerning the fact that they heard about agroecology, $88.9 \%(n=8)$ of the $8^{\text {th }}$ period students of the Agronomic Engineering course at Unitins reported that they knew about this subject at the university, through means of communication such as TV, radio, newspapers, journals, among others, reported by $66.7 \%(n=6)$ of these students; $33.3 \%(n=3)$ heard about this theme in school and $11.1 \%(n=1)$ with relatives. Of the students in the $2^{\text {nd }}$ period, $47.6 \%$ ( $n=10$ ) had their first contact with agroecology at the university, followed by $28.6 \%(n=6)$ from the media, such as TV, radio, newspapers, magazines, among others; $19.0 \%(n=4)$ in school and $14.3 \%$ ( $n=$ 3) with relatives. However, only one student reported ignoring agroecology.

In this sense, Sá-Oliveira, Vasconcelos and Silva (2015) reported that $73.3 \%$ ( $n=$ $157)$ of the $3^{\text {rd }}$ grade students stated they had never heard about agroecology and $11.2 \%$ ( $n=24$ ) of these students, the most common access to the topic had been via the media.

In the study by Soncini, Pierini and Gallo (2016) with students of the first year of the Agronomic Engineering course of the University Center of Araraquara (UNIARA), State of São Paulo, the authors found that $70.3 \%$ ( $n=64$ ) of the students interviewed knew or had already heard about agroecology, however, the knowledge of these students was superficial and based on information obtained by secondary means, such as newspaper articles or television. Based on the results of the present study and the other mentioned studies, the knowledge on agroecology of high school students and students of agronomy courses is still null, incipient and/or superficial, which makes evident the importance of specific disciplines that deal with thematic in the courses of Agronomic Engineering and other courses focused on environmental and agricultural issues.

When asked about what is meant by agroecology, $77.8 \%(n=7)$ of the $8^{\text {th }}$ period students in the present study and $80.9 \%$ (n $=17$ ) of the $2^{\text {nd }}$ period students believe that it is "less aggressive to the environment" (Table 2). 
Table 2. Percentage of the of the interviewed students' answers, on the following question: What do you mean by agroecology?

\begin{tabular}{|c|c|c|c|c|c|c|}
\hline Answers & $\begin{array}{l}\text { To- } \\
\text { tal }\end{array}$ & $\%$ & $\begin{array}{c}\text { Peri- } \\
\text { od }\end{array}$ & $\begin{array}{l}\text { To- } \\
\text { tal }\end{array}$ & $\%$ & $\begin{array}{l}\mathrm{Pe}- \\
\text { riod }\end{array}$ \\
\hline $\begin{array}{l}\text { Socially fairer agriculture in } \\
\text { the countryside }\end{array}$ & - & - & - & 2 & 22.2 & 80 \\
\hline $\begin{array}{l}\text { Agriculture that provides } \\
\text { food for a healthier life }\end{array}$ & 2 & 9.5 & $2 \circ$ & - & - & - \\
\hline $\begin{array}{l}\text { Technique that excludes the } \\
\text { use of agrochemicals for } \\
\text { agricultural production }\end{array}$ & 1 & 4.8 & $2 \circ$ & - & - & - \\
\hline $\begin{array}{l}\text { Agriculture that uses less } \\
\text { aggressive means to the } \\
\text { environment }\end{array}$ & 17 & 80.9 & 20 & 7 & 77.8 & 80 \\
\hline Does not understand & 1 & 4.8 & 29 & - & - & - \\
\hline TOTAL & 21 & 100.0 & - & 9 & 100.0 & - \\
\hline
\end{tabular}

Source: Prepared by the authors.

Differently from this study, that one conducted by Sá-Oliveira, Vasconcelos and Silva (2015) showed that the response related to the less aggressive means to the environment corresponded to $17.8 \%(n=66)$ of the total answers given by $3^{\text {rd }}$ grade high school students. Also in that study, 39.0\% $(n=144)$ of the interviewees said they did not know the term agroecology. However, in this study, only one $2^{\text {nd }}$ period student of Agronomic Engineering mentioned not knowing about agroecology.

Battisti et al. (2015), in a research considering the perceptions about agroecology and techniques of sustainable production of undergraduate students of the Center of Rural Sciences (Agronomic Engineering, Forest Engineering, Veterinary Medicine, Food Technology and Animal Science) of the Federal University of Santa Maria - UFSM, State of Rio Grande do Sul, the authors found that $78.0 \%$ of the students interviewed considered agroecology as "nonharmful processes/aggressors to the environment", which corroborates the concept pointed out by most of the Unitins Agronomic Engineering students interviewed in this research.

According to Feiden (2005), agroecology is a science under construction that studies agro ecosystems, being interdisciplinary and based on knowledge of areas such as agronomy, ecology, economics and sociology, as well as incorporating traditional knowledge. This concept is reinforced by Menegueli et al. (2015), when they state that agroecology is a science under construction, with multidisciplinary characteristics and complex relationships, focused on socially and environmentally based agriculture.

Questioned about the knowledge of some agroecological rural producers in the State of Tocantins, $88.9 \%(n=8)$ of the $8^{\text {th }}$ period students said they did not know any agroecological rural producers in that State. However, one of the $8^{\text {th }}$ period students reported knowing agroecological producers in a municipality in the inner Tocantins, called Miracema. For the $2^{\text {nd }}$ period students, $90.5 \%(n=19)$ reported not knowing any agroecological rural producers in the State. Only two students reported knowing agroecological rural producers, all of them in municipalities in the inner Tocantins (Colméia, Taipas, Pedro Afonso and Pindorama). In similar data, Sá-Oliveira, Vasconcelos and Silva (2015) reported that $88.32 \%$ ( $n=189$ ) of the students interviewed by them mentioned not knowing any agroecological producers.

Although the students are unaware of any agroecological rural producers in the state, according to Silva and Almeida (2007), there are family farming projects in Tocantins regarding fruit growing, such as the São João project, located in the municipality of Palmas; the Manoel Alves project, in the southeast of the State and the pine- 
apple chain project, in the municipalities of Miracema and Barrolândia, inner region of Tocantins. According to these authors, family farming projects related to the cultivation of cassava, rice, milk production, eggs, hen breeding and horticultural products are also found in Palmas.

When asked about how to imagine agriculture in the future, for $44.5 \%(n=4)$ of the $8^{\text {th }}$ period students, agriculture will be based on the agroecology principles, and according to $42.9 \%(n=9)$, agriculture in a few years will be fully technified (Table 3 ).

Table 3. Percentage of the interviewed students' answers, on the following question: How do you imagine the agriculture of the future?

\begin{tabular}{|c|c|c|c|c|c|c|}
\hline Answers & $\begin{array}{l}\text { To- } \\
\text { tal }\end{array}$ & $\%$ & $\begin{array}{c}\text { Peri- } \\
\text { od }\end{array}$ & $\begin{array}{l}\text { To- } \\
\text { tal }\end{array}$ & $\%$ & $\begin{array}{l}\text { Peri- } \\
\text { od }\end{array}$ \\
\hline Fully automated & 9 & 42.9 & 20 & 2 & 22.2 & 80 \\
\hline $\begin{array}{l}\text { Extreme value to organic } \\
\text { and transgenic-free } \\
\text { products }\end{array}$ & 3 & 14.3 & 20 & 2 & 22.2 & 80 \\
\hline $\begin{array}{l}\text { Based on the principles } \\
\text { of agroecology }\end{array}$ & 6 & 28.6 & 20 & 4 & 44.5 & 80 \\
\hline $\begin{array}{l}\text { Concentrated on large } \\
\text { farms }\end{array}$ & 3 & 14.3 & 20 & 1 & 11.1 & 80 \\
\hline TOTAL & 21 & 100.0 & - & 9 & 100.0 & - \\
\hline
\end{tabular}

Source: Prepared by the authors.

Different results were found by SáOliveira, Vasconcelos and Silva (2015), with $3^{\text {rd }}$ grade of high school students, of which the authors reported that for $38.23 \%$ ( $n=$ 112 , agriculture in the future will be of extreme value for organic and transgenic-free products.

On the other hand, agriculture based on the agroecology principles, as mentioned by most of the $8^{\text {th }}$ period students of Agronomic Engineering at Unitins, is in agreement with the studies of Filho et al. (2011), in which the authors report that the future agriculture should be concerned with the production of quality food, with the inputs reduction, especially the chemicals, and with practices that allow to maintain and preserve the natural resources. However, the authors argue that this change will require a joint effort of the public and private sectors.

In this perspective, Caporal, Costabeber and Paulus (2009) argue that the application of agroecology principles to agricultural production systems can draw on the classical teachings of agrarian sciences as well as modern technologies. In summary, it is necessary to be clear that alternative and organic agriculture are usually the result of differentiated techniques and methods application in comparison to the conventional one, normally developed according to the function of regulations and rules that guide the production and impose limits, as, for example, in the use of certain types of inputs.

When questioned about the participation in some theoretical and practical classes related to agroecology, $100 \%(n=9)$ of the $8^{\text {th }}$ period students in this research have already participated in some theoretical class related to agroecology. For them, these classes are essential, important and help to understand the concepts of the area, as seen in the speeches of some of them:

\footnotetext{
"Very productive, didactic, clear and changed my concepts about some things" $\left(A 3,8^{\text {th }}\right.$ period);
}

"It made great incentive for the application of agroecology" (A4, $8^{\text {th }}$ period);

"Extremely enlightening" ( $\mathrm{A} 5,8^{\text {th }}$ period);

"Great. Knowledge of this area is paramount "(A6, $8^{\text {th }}$ period);

"Great lesson, brought new concepts with ex- 
cellent practical examples" (A7, $8^{\text {th }}$ period).

For these students, practical classes help clarify the concepts learned in the classroom and provide a new insight into agriculture, both theoretically and practically, as reported in the speeches of some of the students:

"That one can extract everything from the earth without using the chemicals" $\left(A 4,8^{\text {th }}\right.$ period);

"Interesting because it provided a new vision on agriculture" (A5, $8^{\text {th }}$ period);

"Of great importance for the knowledge of the room" (A6, $8^{\text {th }}$ period);

"We work with biodiversity indexes. It was very interesting to see the conditions to reach an environmental balance " $\left(A 7,8^{\text {th }}\right.$ period);

"The lesson was essential for the theoretical teachings" (A9, $8^{\text {th }}$ period).

Regarding the $2^{\text {nd }}$ period students, $76.2 \%$ ( $n=16$ ) said they did not have theoretical and practical classes related to agroecology, with $23.8 \%(n=5)$ and participated in some lecture and/or lecture about the theme. As reported in the speeches of these students, the classes and/or lectures were important and aroused great interest on the subject, facilitating the understanding of its benefits:

"Very important because it explains the benefits of sustainable management" $\left(A 9,2^{\text {nd }}\right.$ period);

"I found it very interesting because it deals with aspects of production that do not affect the environment so much" (A14, $2^{\text {nd }}$ period);
"Well cool, I got more knowledge in the industry" (A16, $2^{\text {nd }}$ period);

"Interesting and of great importance" (A18, $2^{\text {nd }}$ period).

Although the discipline of agroecology is taught only in the $7^{\text {th }}$ period of the Agronomic Engineering course at Unitins, the above data shows that interest in the subject was aroused in some of the students yet in the first grade of the course. On the other hand, in the study by Battisti et al. (2015), 81.0\% of undergraduate students at the UFSM Center for Rural Sciences reported practical insufficiency in ecological and sustainable production issues. In addition, $88.0 \%$ of these students reported never or rarely having the subject of agroecology addressed in the classroom.

Still, 33.3\% $(n=3)$ of the students interviewed from the $8^{\text {th }}$ period have already been part of some research project related to agroecology, all of them being scientific initiation projects. However, $66.7 \%(n=6)$ of these students expressed interest in participating in research and/or extension projects with the subject matter. For the $2^{\text {nd }}$ period students, $95.3 \%(n=20)$ did not participate in any research project and/or extension related to agroecology, but only one of these students reported having no interest in the area and participation in research and/or extension projects on the subject. One of the students of the second period reported that he was working with agroecology in a scientific initiation project. In this respect, it is important to emphasize that research and/or extension projects related to agroecology should be more encouraged, since the university has as its role in the professionals training, based on the principle of inseparability of teaching, research and extension (SANTOS, 2004). 
In this sense, it is understood that extension projects on agroecology should be more encouraged in undergraduate courses in Agronomy Engineering in Brazil, according to the study by Escosteguy et al. (2015). In this study, the authors reported actions developed in an extension project entitled "Structuring actions for value aggregation in agroecological transition properties", which aimed to support families with regard to the organizational and legal aspects for the formalization of rural family agroindustries in agroecological transition in and around the municipality of Pelotas, in the State of Rio Grande do Sul. According to the authors, the project allowed the approach of the academy with the community and provided actions of practical and theoretical support with the local reality. Experiences such as these provide the construction of knowledge, essential for professional training and allows to experience in situ the experiences observed, being fundamental for the rural production through the use of the agroecology principles.

When asked about the knowledge of sustainable food production practices, $100 \%$ (n $=9$ ) of the $8^{\text {th }}$ period students interviewed in this study answered they knew about these practices, being referred to as green manuring, natural fertilizers or bioinsecticides, biological pest control, of crops, minimum cultivation, composting, agroforestry systems and crop, livestock and forest integration. On the other hand, 33.3\% $(n=7)$ of the $2^{\text {nd }}$ period students answered they did not know about sustainable food production practices, since $66.7 \%(n=14)$ of those who said they knew reported practices such as organic fertilization, community gardens that do not use agrochemicals, low carbon agriculture, agroforestry systems, crop inte- gration, livestock and forest integration, pest control, composting, subsistence production or harvesting and small scale production.

In this line of thought, Sá-Oliveira, Vasconcelos and Silva (2015) reveal fourteen students answering that they did not know anything about that, which leads to interpret a mismatch between the knowledge, the habit of life of the students and, possibly, the didactic practice of their teachers with the current environmental problems and the possibilities of minimizing these problems, especially those related to the production of agroecological or organic foods.

When asked if they had already consumed any agroecological products, $66.7 \%$ $(n=6)$ of the students in the $8^{\text {th }}$ period and $57.2 \%\left(n=12\right.$ ) of the $2^{\text {nd }}$ period responded positively. They mentioned vegetables such as lettuce, arugula and cabbage, vegetables such as carrots and cucumbers, fruits such as tomato, mango, cashew, coconut, guava, apple and watermelon, cereals such as rice, legumes such as beans and tubers such as cassava. However, $33.3 \%(n=3)$ of the students of the $8^{\text {th }}$ period reported not consuming agroecological products due to the high price, low availability and the culture of non-consumption, as reported in the speeches of some of the students:

\footnotetext{
"They are usually expensive and I opt for the cheapest" (A2, $8^{\text {th }}$ period);

"Low market availability and high price" (A6, $8^{\text {th }}$ period);

"First high price and the cultural issue" (A9, $8^{\text {th }}$ period).
}

For some of the students of the second 
period who mentioned having not consumed agroecological products, they reported not knowing what would actually be an agroecological food, and information about their production, as was clear in their lines:

"I do not know if the product is agroecological or not" (A9, $2^{\text {nd }}$ period);

"It has no information about the product and how it is produced" $\left(A 13,2^{\text {nd }}\right.$ period);

"I Do not know if it was an agroecological product" (A17, $2^{\text {nd }}$ period);

"Because I had no information as to whether or not it was an agroecological product" (A19, $2^{\text {nd }}$ period).

According to Sediyama, Santos and Lima (2014), the vegetables production in an organic system is one of the activities in increasing expansion, being produced mainly by family farmers. In another study that aimed to characterize the consumer market of organic foods in the city of Belo Horizonte, State of Minas Gerais, as well as the habits and the main motivations and limitations in relation to the consumption of organic foods, Andrade and Bertoldi (2012) found that $81.5 \%$ of people interviewed consume organic fruits and vegetables weekly, with only $16.5 \%$ saying they consume other organic foods, including fruit products $(67.8 \%)$, grain products and cereals $(21.5 \%)$, bee products $(9.2 \%)$ and vegetable products (1.5\%). For these people, the greatest motivation for consuming organic food comes down to the concern for health, higher nutrient content and the most pronounced flavor of these foods.

Still on this reflection, in the study of Cavallet et al. (2013) on the detection of the knowledge of the population about organic product in the coastal region of Paraná, the authors found that $49.5 \%$ of the interviewees had already consumed some organic product, with lettuce and tomato being the most consumed items in the region. According to the same authors, this data shows that horticulture is an important activity for the definition of agricultural crops for cultivation in an organic system of production, with a view to local consumption. It is important to emphasize that one of the advantages of the organic production system is related to the non-use of chemicals. Vilela et al. (2006) point out that the advantages of organic versus conventional consumption have to do with the lower toxicity index and the maintenance of environmental balance. It is also known that producers are satisfied to offer consumers better quality products and to promote improvements to the population close to the production sites, considerably reducing environmental contamination (PANZENHAGEN et al., 2008). In addition, the non-use of agricultural pesticides would help prevent a number of diseases, including dermatoses, cancer and neurological sequelae (AZEVEDO, 2006).

When asked about the concept of environmental service, $100 \%(n=9)$ of the $8^{\text {th }}$ period students of the Agronomic Engineering course are unaware of the concept. For $80.9 \%$ ( $n=17$ ) of the second period students, the concept of environmental service is also unknown. This information is in dialogue with the study by Sá-Oliveira, Vasconcelos and Silva (2015), because $85.0 \%$ of the students of the $3^{\text {rd }}$ year of High School reported not knowing the concept of environmental service. However, for $19.0 \%$ ( $n=$ 4 ) of the $2^{\text {nd }}$ period students of the Agronomic Engineering course at Unitins, envi- 
ronmental service can be conceptualized as "Measures aimed at protecting the environment and supervising human actions in this environment" and "Precious for the well-being of the environment." According to Wunder (2015), environmental service can be conceptualized as the benefits to the people's quality of life associated with the adoption of natural resource management practices.

Regarding the soy monoculture installed in Tocantins, $88.9 \%(n=8)$ of the $8^{\text {th }}$ period students and $85.7 \%(n=18)$ of the $2^{\text {nd }}$ period understood that it is a good initiative financially and environmentally poor. Only $11.1 \%(n=1)$ of the $8^{\text {th }}$ period students said that it is a bad environmental and financial initiative for the State of Tocantins. For $9.5 \%(n=2)$ of the second period students, soy monoculture is a good financial and environmental initiative for the population of the State. According to Silva and Almeida (2007), soybean is the main crop of the municipality of Palmas, in planted and production area.

According to $100 \%(n=9)$ of the $8^{\text {th }}$ period students, agroecological initiatives would be supported in their municipalities with knowledge acquired at the university, through specialized assistance to rural producers and sustainable practices. This fact is stated by some of these students:

"Contributing with acquired knowledge in the college" (A1, $8^{\text {th }}$ period);

"With technical assistance and encouragement of small producers" $\left(\mathrm{A} 2,8^{\text {th }}\right.$ period);

"Community-based agro-ecological gardens" (A3, $8^{\text {th }}$ period);

"Using resources to present the model of an agroecological system for producers" $\left(\mathrm{A} 4,8^{\text {th }}\right.$ period);

"In the implementation of projects or with assistance" (A7, $8^{\text {th }}$ period);

"Implementation of consortium system" (A8, $8^{\text {th }}$ period);

"It would encourage trade with sustainable practices through courses" (A9, $8^{\text {th }}$ period).

For the $2^{\text {nd }}$ period students, $90.5 \%$ ( $n=$ 19) would support agroecological initiatives in their municipality through the dissemination to family and friends, awareness, management information and low cost solutions, as can be verified in the speech of some of them:

"Disclosure of importance to friends and family" (A3, $2^{\text {nd }}$ period);

"Informing producers of management techniques" (A9, $2^{\text {nd }}$ period);

"Practical and theoretical dissemination and support" (A12, $2^{\text {nd }}$ period);

"Making people aware of the benefits of agroecology" (A14, $2^{\text {nd }}$ period);

"So that it does not bring environmental impacts with more sustainable use of water and techniques that reduce deforestation, such as crop, livestock and forest integration" (A19, $2^{\text {nd }}$ period);

"There are productive and low cost solutions such as crop, livestock and forest integration and aquaponics" (A21, $2^{\text {nd }}$ period).

Furthermore, 9.5\% ( $n=2)$ of these students would not support agroecological initiatives in their municipality, with one of the students reporting that he did not know about agroecological initiatives "I am not 
aware of any" (A18, $2^{\text {nd }}$ period). It is important to mention that support for agroecological initiatives is important, since agroecology must be recognized by the various sectors of society as a new way of promoting sustainable rural development.

It is emphasized that questions on agroecology can be acquired and taught, making possible to experience the theme in theory, practice and day by day. It is also worth mentioning that each human being reacts and responds differently to the actions on the environment in which he/she lives, being this experience the result of cognitive processes, individual perceptions and expectations (FERNANDES; PELISSARI, 2003). In addition to it, knowledge on the subject allows the professional of Agronomic Engineering to see the best actions to be taken in the field in front of agroecology.

\section{CONCLUSION}

The data revealed the fact that a significant portion of these university students' families own rural property, where they usually attend on weekends and/or vacations, and this reinforces that a good part of the students who are looking for courses of Agronomic Engineering have some connection with the countryside.

Most of the students of the two periods have already heard about agroecology, and the university was the mean where most of them got the knowledge through the media, such as TV, radio, newspapers, magazines, among others. Besides, they conceptualized agroecology as agriculture that uses less aggressive means to the environment, which corroborates that found in other studies on the same subject, but researched and analyzed in different contexts.
Despite the existence of agroecological rural producers in several municipalities in the state of Tocantins, most of the students of the two periods mentioned that they did not know any agroecological rural producers in that State. For most students in the $8^{\text {th }}$ period, agriculture will be based on the agroecology principles, but for most of the second period students, agriculture in a few years will be fully technified, which shows two very divergent perspectives on the same subject studied at the university.

Even if the agroecology discipline was offered in the $7^{\text {th }}$ period of the course, where all the $8^{\text {th }}$ period students interviewed in this study participated, five students from the $2^{\text {nd }}$ period would have reported a participation in some lecture with regards to it. For the students, practical classes help clarify concepts learned in the classroom and provide insight into agriculture.

In addition, most of the students interviewed in this study expressed interest in participating in research and/or extension projects on agroecology, which is important for the knowledge production and for the scientific advance in the area. Most of the interviewed students in the two periods said they knew about sustainable food production practices by citing, for example, green manure, natural fertilizers or bioinsecticides, biological pest control, crop rotations, minimum cultivation, composting, agroforestry systems and crop integration, livestock and forest.

They also said having already consumed some agroecological products such as vegetables, fruits, cereals and tubers, and that they would support agroecological initiatives in their municipalities with the knowledge acquired at the university, through specialized assistance to rural pro- 
ducers and sustainable practices.

However, most students are unaware of the environmental service concept and believe that the soy monoculture installed in Tocantins is a good initiative financially and environmentally poor.

This study allowed to obtain information about the perceptions of the Agronomic Engineering students of Unitins with respect to agroecology. It also allowed us to understand the perceptions of students in the $2^{\text {nd }}$ and $8^{\text {th }}$ periods of the course, if they are different or not. However, it is suggested that there be continuity of approaches involving the subject agroecology in the specific disciplines, as well as those offered in the common core, so that there can be an integration between the knowledge and practices in the courses offered by the institution and also in other courses of Agronomic Engineering in Brazil.

\section{REFERENCES}

ANDRADE, L.; BERTOLDI, M. Atitudes e motivações em relação ao consumo de alimentos orgânicos em Belo Horizonte-MG. Food Technology, p. 31-40, 2012.

AZEVEDO, E. Alimentos orgânicos: ampliando os conceitos de saúde humana, ambiental e social. Tubarão: Editora Unisul, 2006.

BARDIN, L. Análise de conteúdo. Lisboa, Portugal: Edições 70, 2009.

BARROS, A, LEHFELD, N. Projeto de Pesquisa: propostas metodológicas. Petrópolis: Vozes, 1990.

BATTISTI, L. O. et al. Produção de base ecológica e agroecologia na percepção de estudantes de Ciências Agrárias da Universidade Federal de Santa Maria (UFSM). In: Memorias Del $V$ Congresso Latino Americano de
Agroecologia, 2015.

CAPORAL, F. R.; COSTABEBER, J. A.; PAULUS, G. Agroecologia: uma ciência do campo da complexidade. Brasília. 2009.

CAVALLET, L. E. et al. Conhecimento da população sobre produto orgânico na região litorânea do Paraná. Revista Brasileira de Agroecologia, v. 8, n. 2, p. 62-74, 2013.

DIAS. A formação do agrônomo como agente de promoção do desenvolvimento. Revista Extensão Rural, ano XV, Jan - Jun, p. 53-68, 2008.

ESCOSTEGUY, I. L. et al. Reflexões sobre um projeto de extensão: contribuições para o desenvolvimento da agroecologia no município de Pelotas, RS. Expressa Extensão, Pelotas, v. 20, n. 2, p. 71-86, 2015.

FEIDEN, A. 2005. Agroecologia: introdução e conceitos. In: Aquino, A.M.; Assis, R.L. (orgs.). Agroecologia: princípios e técnicas para uma agricultura orgânica sustentável. Embrapa, Brasília. Pp. 49-69.

FILHO, K. E. et al. O papel da ciência e da tecnologia na agricultura do futuro. Revista de Política Agrícola, Ano XX, n. 4, p. 98-111, 2011.

FERNANDES, R. S.; PELISSARI, V. B. Como os jovens percebem as questões ambientais. Revista Aprender, v. 13, n. 4, p.10-15, 2003. LIMA, A. J. P.; CARMO; M. S. Agricultura sustentável e a conversão agroecológica. Desenvolvimento em Questão, v.4, n.7, p.47-72, 2006.

LUCENA, T. C.; FIGUEROA, M. E. V.; OLIVEIRA, J. C. A. Educação ambiental, sustentabilidade e saúde na criação de uma horta escolar: Melhorando a qualidade de vida e fortalecendo o conhecimento. Revista Brasileira de Educação e Saúde, v. 5, n. 2, p. 01-09, 2015.

MENEGUELI, H. O. et al. Agroecologia brasileira no marco do plano nacional de agroe- 
cologia e produção orgânica: cenário atual, perspectivas e desafios. Revista Enciclopédia Biosfera, v.11, n. 22; p. 29-45, 2015. MINAYO, M. C. S. Análise qualitativa: teoria, passos e fidedignidade. Ciência \& Saúde Coletiva, Rio de Janeiro, v. 17, n. 3, p. 621626, mar. 2012

OLIVEIRA, C. S. P.; LIMA, A. F. Acadêmicos das Ciências Ambientais: percepção e interesse pelo setor agroecológico. Scientia Agraria Paranaensis, v. 16, n. 1, jan./mar., p. 39-44, 2017.

PANZENHAGEN, N. V. et al. Aspectos técnico-ambientais da produção orgânica na região citrícola do Vale do Rio Caí, RS. Ciência Rural, v. 38, n. 1, p. 90-95, 2008. https:// doi.org/10.1590/S0103-84782008000100015

PROJETO POLÍTICO PEDAGÓGICO DO CURSO DE ENGENHARIA AGRONÔMICA. Universidade Estadual do Tocantins/UNITINS. Palmas: Governo do Estado do Tocantins, 2010.

RAMOS, P. R. et al. Agroecologia e meio ambiente: percepção dos estudantes do ensino técnico integrado e superior no IFMT, Campus Confresa. In: XIII Congresso Nacional de Meio Ambiente de Poços de Caldas, 2016.

SANTOS, B. S. A universidade no séc. XXI: para uma reforma democrática e emancipatória da Universidade. São Paulo: Cortez, 2004.

SÁ-OLIVEIRA, J. C.; VASCONCELOS, H. C. G.; SILVA, E. S. A Agroecologia na percepção de alunos de ensino médio de quatro escolas públicas na cidade de Macapá-Amapá. Biota Amazônia, Macapá, v. 5, n. 3, p. 98-107, 2015. https://doi.org/10.18561/2179-5746/ biotaamazonia.v5n3p98-107

SEDIYAMA, M. A. N.; SANTOS, I. C.; LIMA, P. C. Cultivo de hortaliças no sistema orgânico. Revista Ceres, v. 61, Suplemento, p. 829-
837, nov/dez, 2014. https://doi.org/10. 1590/0034-737x201461000008

SILVA, A. R. P., ALMEIDA, M. G. O agronegócio e o estado do Tocantins: o atual estágio de consolidação. Caminhos de Geografia, v. 8, n. 21, p. 28-45, 2007.

SIMONETTI, A. P. M. et al. Caracterização do perfil dos alunos ingressantes 2015 no Curso de Agronomia da Faculdade Assis Gurgacz - Cascavel - PR. Revista Cultivando o Saber, v. 8, n. 4, p. 357-372, 2015.

SONCINI, A., PIERINI, A. J., GALLO, Z. A compreensão dos alunos do primeiro ano do curso de agronomia da UNIARA sobre agroecologia: uma análise do presente e perspectivas de futuro. Retratos de Assentamentos, v. 19, n. 2, p. 294-314, 2016.

VILELA, N. J. et al. Perfil dos consumidores de produtos orgânicos no Distrito Federal. Brasília, DF: Embrapa Hortaliças, 2006.

WUNDER, S. Revisiting the concept of payments for environmental services. Ecological Economics, v. 117, p. 234-243, 2015. https://doi.org/10.1016/j.ecolecon.2014.08 .016

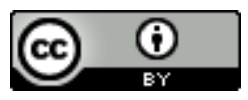
License information: This is an openaccess article distributed under the terms of the Creative Commons Attribution License, which permits unrestricted use, distribution, and reproduction in any medium, provided the original work is properly cited.

Article received on October 06, 2018.

Evaluated February 01, 2019.

Accepted on February 07, 2019.

Published on February 28, 2019.

How cite this article (ABNT):

OLIVEIRA, Deyla Paula de; RAMOS, Michele Ribeiro; PEREIRA, Arison José. Agronomic Engineering students' perceptions about agroecology: a case study at a public university in Tocantins. Estação Científica (UNIFAP), Macapá, v. 8, n. 2, p. 09-22, may/apr. 2018. 